\title{
Concentrations of heavy metals in fish from coastal waters around the Baltic Sea (Extended abstract)
}

\author{
Heinz-Rudolf Voigt
}

\author{
Voigt, H.-R. 1999. Concentrations of heavy metals in fish from coastal waters around \\ the Baltic Sea (Extended abstract). - ICES Journal of Marine Science, 56 Supplement: \\ $140-141$ \\ (C) 1999 International Council for the Exploration of the Sea
}

Key words: Heavy metals, coastal fish, Baltic Sea.

H.-R. Voigt: Department of Limnology and Environmental Protection, University of Helsinki, Helsingfors, A-building, Vik., PO Box 27, FIN 00014, Finland.

Preliminary results are presented from analyses of heavy metal concentrations in liver and muscle tissue of some pelagic and demersal fish species caught in coastal areas of the Baltic Sea. Herring (Clupea harengus membrans L.) has been chosen as a pelagic species reflecting the situation in the open sea, while the benthic, and more stationary, flounder (Platichthys flesus L.) and eelpout (Zoarces viviparus L.) have been considered to describe the situation in the coastal waters. In addition, smelt (Osmerus eperlanus L.h) has been included as a pelagic species; it is more stationary than herring and competes partly for the same food, although mainly feeding on benthic organisms.

Fish samples were collected in some coastal areas of Finland (Åland Islands - 1: Nåtö, 2: mouth of the river Kokemäenjoki-Kumo; Archipelago Sea - 3: NaguKorpo; Hanko-Hangö peninsula - 4: Tvärminne), Estonia (5: Muuga and 6: Väinameri-Matsalu Bay), Latvia (Riga Bay - 7: Kolka), and Germany (8: Kiel Bay and 9: Kiel harbour).

In contrast to the standard analytical procedure used in the Baltic monitoring program (authorized by HEL$\mathrm{COM}$ ), measurements have not been based on homogenates of several specimens of fish (including tissues and organs), but on individual specimens and on liver and muscle tissue separately. Therefore, comparisons with published data are difficult and have not been attempted. For each species, at least 15 and up to 20 specimens of approximately the same size have been analysed per station, both sexes included.

The metals analysed are: mercury $(\mathrm{Hg})$ by CVAAS (results in $\mathrm{mg} \mathrm{kg}^{-1}$ wet weight); iron $(\mathrm{Fe})$, manganese
$(\mathrm{Mn})$, zinc $(\mathrm{Zn})$, copper $(\mathrm{Cu})$ by AAS with an acetylene flame AAS, and cadmium $(\mathrm{Cd})$, lead $(\mathrm{Pb})$, and nickel (Ni) by AAS in a graphite oven (results in $\mathrm{mg} \mathrm{kg}^{-1}$ dry weight).

Results for the liver are summarized in Table 1. With the exception of mercury, the metal concentrations were in most cases distinctly higher in liver than in muscle tissue and differences among species and areas were generally most pronounced in the former. Therefore, these have been used here for a first comparison. Since a complete data set is not yet available for all species and area combinations, a comparison between the four selected species can be made only for Tvärminne and Muuga. Based on liver values, herring is the species with the highest concentration of mercury at both stations, smelt is highest for manganese, eelpout for iron, zinc, and for cadmium at Muuga, and flounder is highest for copper and for cadmium at Tvärminne.

For a comparison among stations, the data set is most complete for eelpout and covers all stations except Nåtö and Kumo älv. Obvious local maxima in liver values are apparent for iron, zinc, and cadmium at Tvärminne and Muuga. Flounder, which includes Nåtö but excludes some other stations, also yielded maxima at Tvärminne and Muuga for iron, zinc, copper, and cadmium, but high values of the same metals were also observed at Nåtö.

As the recorded levels of some metal concentrations are remarkably high even in areas such as the Aland Islands, which are generally regarded as almost unaffected by pollution, there is obviously a need for further detailed investigations. 
Table 1. Concentrations of heavy metals in liver of smelt (O.e.), herring (C.h.), eelpout (Z.v.), and flounder (P.f.) in coastal areas of the Baltic (1: Nåtö; 2: Kokemäenjoki-Kumo river; 3: Nagu-Korpo; 4: Tvärminne; 5: Muuga; 6: Väinameri-Matsalu Bay; 7: Kolka; 8: Kiel Bay; 9: Kiel harbour): mercury $(\mathrm{Hg})$ in $\mathrm{mg} \mathrm{kg}^{-1}$ wet weight; iron $(\mathrm{Fe})$, manganese $(\mathrm{Mn})$, zinc $(\mathrm{Zn})$, copper $(\mathrm{Cu})$, cadmium $(\mathrm{Cd})$, lead $(\mathrm{Pb})$, and nickel $(\mathrm{Ni})$ in $\mathrm{mg} \mathrm{kg}^{-1}$ dry weight (highest values for each species metal combination are given in bold face).

\begin{tabular}{|c|c|c|c|c|c|c|c|c|c|c|}
\hline & Area & 1 & 2 & 3 & 4 & 5 & 6 & 7 & 8 & 9 \\
\hline \multirow[t]{4}{*}{$\mathrm{Hg}$} & O.e. & & 0.07 & 0.03 & 0.05 & 0.04 & 0.05 & & & \\
\hline & C.h. & & & 0.15 & 0.30 & 0.32 & & & & \\
\hline & L.v. & & & 0.04 & 0.02 & 0.05 & 0.06 & 0.02 & 0.04 & 0.07 \\
\hline & P.f. & 0.05 & & & 0.07 & 0.03 & & & 0.01 & 0.04 \\
\hline \multirow[t]{4}{*}{$\mathrm{Fe}$} & O.e. & & 303 & 101 & 185 & 228 & 144 & & & \\
\hline & C.h. & & & 287 & & 200 & & & & \\
\hline & Z.v. & & & 416 & 809 & 1190 & 453 & 748 & 518 & 234 \\
\hline & Pl.f. & 947 & & & 459 & 151 & & & 181 & 251 \\
\hline \multirow[t]{4}{*}{$\mathrm{Mn}$} & O.e. & & 10.1 & 8.6 & 18.6 & 7.6 & 9.5 & & & \\
\hline & C.h. & & & 4.0 & & 6.8 & & & & \\
\hline & Z.v. & & & 3.1 & 5.9 & 3.2 & 5.2 & 4.6 & 2.0 & 1.8 \\
\hline & P.f. & 2.9 & & & 4.5 & 2.6 & & & 3.2 & 1.8 \\
\hline \multirow[t]{4}{*}{$\mathrm{Zn}$} & O.e. & & 128 & 82 & 63 & 98 & 116 & & & \\
\hline & C.h. & & & 105 & & 93 & & & & \\
\hline & Z.v. & & & 93 & 111 & 145 & 94 & 62 & 94 & 73 \\
\hline & P.f. & 105 & & & 126 & 109 & & & 80 & 81 \\
\hline \multirow[t]{4}{*}{$\mathrm{Cu}$} & O.e. & & 9.8 & 4.3 & 5.9 & 6.3 & 4.4 & & & \\
\hline & C.h. & & & 9.7 & & 9.9 & & & & \\
\hline & Z.v. & & & 15.6 & 14.9 & 21 & 11.5 & 7.4 & 22.6 & 26.9 \\
\hline & P.f. & 52.5 & & & 96.1 & 35.6 & & & 31.3 & 40.8 \\
\hline \multirow[t]{4}{*}{$\mathrm{Cd}$} & O.e. & & 0.19 & 0.04 & 0.13 & 0.11 & 0.2 & & & \\
\hline & C.h. & & & 0.18 & & 0.54 & & & & \\
\hline & Z.v. & & & 0.42 & 0.78 & 2.09 & 0.38 & 0.26 & 0.18 & 0.16 \\
\hline & P.f. & 3.12 & & & 3.39 & 0.51 & & & 0.04 & 0.11 \\
\hline \multirow[t]{3}{*}{$\mathrm{Pb}$} & O.e. & & 0.2 & 0.1 & 0.3 & & 0.2 & & & \\
\hline & Z.v. & & & 0.2 & 0.8 & 1.1 & & 0.3 & 0.3 & 0.2 \\
\hline & P.f. & 0.2 & & & 0.1 & & & & 0.3 & 0.1 \\
\hline \multirow[t]{4}{*}{$\mathrm{Ni}$} & O.e. & & 0.7 & 0.1 & 0.6 & & 0.3 & & & \\
\hline & C.h. & & & 0.1 & & & & & & \\
\hline & Z.v. & & & 0.1 & 1.2 & 0.6 & & 0.4 & 0.5 & 0.4 \\
\hline & P.f. & 0.8 & & & 0.8 & & & & 0.1 & 0.1 \\
\hline
\end{tabular}

